\title{
Foreword by Hubert Hermans
}

\section{Prefacio por Hubert Hermans}

\author{
Hubert Hermans \\ Catholic University of Nijmegen
}

\begin{abstract}
When a society becomes more complex and heterogeneous, the identity of teachers "is also challenged to become more complex and heterogeneous. The school, as a reflection of society, needs flexible educators, capable of adapting to change. From the perspective of Dialogical Self Theory, this flexibility translates into the need to adopt a multiplicity of positions of the self as involved in permanent dialogue. These I-positions have the quality of being individual, but also social and their coalition with the I-positions of others can generate shared positions or Wepositions. This is an indispensable condition to achieve the successful development of innovative educational projects. Among the different functions that I-positions can adopt, two are crucial. The activation of meta-positions that allow reflection on the other, more specific, positions and promoter-positions that provide a developmental impetus and direction to the other positions. The text ends by underlining the relevance of this dialogical perspective to the contemporary world.
\end{abstract}

Keywords: Social Change; Educational Models; multiplicity of I-positions: Dialogical Self Theory

\section{Resumen}

Cuando la sociedad se vuelve más compleja y heterogénea, la identidad de nuestros maestros es también desafiada para convertirse en más compleja y heterogénea. La escuela, reflejo de la sociedad, precisa de educadores flexibles, capaces de adaptarse a los cambios. Desde la perspectiva de la Dialogical Self Theory esta flexibilidad se traduce en la necesidad de adoptar una multiplicidad de posiciones del yo involucrado en un diálogo permanente. Estas I-positions tienen la cualidad de ser individuales, pero también sociales y su coalición con las I-positions de otros puede generar posiciones compartidas o We-positions. Se trata de una condición indispensable para lograr el desarrollo exitoso de proyectos educativos innovadores. Entre las distintas funciones que pueden adoptar la I-positions, dos resultan clave. La activación de meta-posiciones que permite la reflexión sobre otras posiciones, más específicas, y las posiciones-promotoras que proporcionan impulso y dirección en el desarrollo de otras posiciones. El texto finaliza subrayando la relevancia de esta perspectiva dialógica en el mundo contemporáneo.

Palabras clave: Cambio Social; Modelos educativos; Multiplicidad de posiciones del yo; Teoría del yo dialógico 
Reading the different articles of this stimulating and innovating work, I was wondering if there is a commonality underlying all articles of this special issue. I arrived at the following insight: when society is becoming more complex, the identity of our teachers is becoming more complex too. Moreover, when society changes more rapidly, teacher identity changes more rapidly too. As never before, teachers are challenged to give an adequate response to the accelerating alterations of educational theories, practices, and institutions and to evaluate their value for education in a complex society. In other words, teaching and learning are no longer to be understood as purely individual enterprises and even not as isolated teacher-student interactions, but as processes that take into account the comprehensive historical and cultural changes in the society at large.

Over the course of time, society has been subjected to dramatic changes, even within one lifetime. Personally, I have vivid memories about the forties and fifties of the past century when I received my primary and secondary education in The Netherlands. Students in that time period had a clear goal in mind (e.g., becoming a doctor, teacher, administrator, worker) and had the prospect to live and work in a relatively stable and homogeneous society. A school career was a linear trajectory towards a societal position that one would occupy for the rest of one's life with the guarantee of stable income and social status. That situation has been changed enormously in our contemporary society that has become more heterogeneous, boundary-crossing, and subjected to processes of globalization. Present-day education provides us, more than ever before, with new opportunities, such as studying abroad, visiting other cultures, global connections, the use of social media, and new technological learning facilities. At the same time, this society confronts us with new challenges and threats, such as wide-spread immigration, climate change, the spread of pandemics, economic uncertainty, job change or job loss as the result of robotics and artificial intelligence. In this complex society, laden with strong contrasts and unexpected changes, educational institutions are challenged to increase the capacity of teachers and students to give an adequate response to these changes. Education in this society requires us to learn and teach not only as individuals but also as social beings and as participants of groups and networks, flexible enough to find their way in constantly changing situations.

\section{THREE LEARNING STRATEGIES: FROM INDIVIDUAL TO SOCIAL BEING}

Reading this thought-provoking special issue, I realized that education is changesensitive and is moving into a direction that fits more than before with a heterogeneous, border-crossing society. Education is transforming itself from a focus on individual learners who make progressive steps towards a unidirectional 
future to social learners who create new forms of cooperation, use multi-media technologies and move into a multi-directional future.

In their thorough introductory article of this special issue, Monereo and Badia provide us with a broad spectrum of educational innovations that, in my view, show how teaching and learning are intensely connected with significant societal changes. One of the distinctions they make is between acquisition of knowledge, construction of knowledge, and social co-construction of meanings. The first one, the acquisition of knowledge, demonstrates how teachers increase their existing knowledge by acquiring contents that are to a great degree predetermined. Through direct instructions, these teachers convey this body of knowledge to their students who are addressed as 'recipients' and expected to reproduce this knowledge without much use of their imagination and creativity. This is very different from the second educational strategy, construction of knowledge that explains how existing teacher instructions can be modified and enriched, resulting in new constructions that go beyond existing knowledge. An example of this is the use of techniques that enable teachers to gain access to complex, critical thinking processes. Teachers may stimulate the critical thinking of their students and the construction of new knowledge that goes beyond traditional theory and practice. The third strategy, social co-construction of meaning has the most affinity with the basic message of this special issue. It addresses teachers as participants in a group, community or professional network who build socially shared meanings on the basis of their existing individual knowledge. This strategy enables teachers to form learning communities in which they are engaged in the negotiation of meanings with other teachers. Likewise, they teach this strategy to their students who are approached as social beings who can learn both from their teachers and their co-students. It impresses me that the learning process in this educational strategy is more non-linear, more multi-directional, less predictable, and more explorative than the previous ones and, as such, more fitting to a boundary-crossing, network-oriented, globalizing, and heterogeneous society.

\section{SELF AS A MULTIPLICITY OF I-POSITIONS}

I was pleasantly surprised to notice that all articles of this special issue are, more or less, inspired by Dialogical Self Theory (DST; Hermans \& Hermans-Konopka, 2010), which adds to the coherence of the special issue as an integrated conceptual construction. This theory brings together two classic developments in the social and literary sciences. As a theory of the self it is inspired by the works of American pragmatists, like William James and George $\mathrm{H}$. Mead. As referring to the notion of dialogue the theory is influenced by the writings of the Russian 
literary scholar Mikhail Bakhtin. Traditionally, the self is understood as referring to processes taking place within the person, while dialogue is conceived of as happening between different persons or groups of persons. The composite concept 'dialogical self' is explicitly devised to transcend this self-society dichotomy. Bringing self and dialogue together in one concept allows the "between"' to enter the 'within', so that other individuals and groups are adopted as 'othersin-the-self.' As such, others have the potential to co-construct the self and directly contribute to its organization and reorganization. In reverse, DST brings the 'within' to the 'between', so that what happens within the individual is working as a process that contributes, directly and intrinsically, to the social and societal context of the self. In this way, self becomes society-inclusive and society becomes self-inclusive (Hermans, 2018).

In its most succinct form, the dialogical self can be defined as a 'dynamic multiplicity of I-positions in the society of the mind, intensely connected as it is with the minds of others.' The seemingly static notion of 'I-position' refers, in fact, to a highly dynamic process of positioning, in which persons place themselves or are placed vis-a-vis real or imagined others. In this conception the self is located in time and space. From a spatial perspective, the self is part of a process of positioning and counter-positioning in which the other is moving towards, against, or away from the other. From a temporal perspective, the self is involved in a process of positioning and repositioning dependent on changes in time and space. An I-position can be personal-as the way of organizing one's private life (e.g., I as dreamer, music lover, spiritual, humorous)-or social-as subjected to public expectations and prescriptions- (e.g., I as father, colleague, teacher, member of a sports club). Typically, personal and social positions form coalitions. For example, one teacher (social position) finds it important to use humor (personal position), whereas the other one emphasizes clarity and precision (personal position). In this way, people can give their personal 'touch' to the professional roles they play in society. A basic idea in this theory is that the self can occupy a multiplicity and complexity of I-positions and is able to move from one position or coalition of positions to another one dependent on changes in time and space.

For the social co-construction of meaning, the distinction between internal and external I-positions is essential. Positions are not only internal (e.g., I as a man, teacher, husband) but also external, that is, as belonging to the extended domain of the self (e.g., my wife, my children, my students, my sport mates, my opponent). Usually, internal and external positions form combinations (e.g., I as a mother of three lovely children, I as a teacher of a difficult class, I as an opponent to demagogic political leaders). An important implication of this 
distinction is that one's internal positions are co-organized by the other as 'another l' (external position). In the self of the student the teacher as significant other is incorporated as other-in-the-self with the implication that students can perceive, interpret, and evaluate the world from the perspective of their teachers and incorporate this perspective in the organization of their own (internal) Ipositions. A similar process takes place in the students' self when, during cooperation with other students, the internal domains of their selves are co-organized by their peers as external positions. In other words, the self is intrinsically social, that is, the other is not simply 'outside' but plays an influential role in the intimate domain of the self and its organization.

For group and team work in educational situations, the extension of I-positions to we-positions is significant. A we-position is a fusion of an I-position of one person with those from another person. It is a collective position shared by a group of people, for example, a team of teachers who cooperate on a task, have a common purpose or discuss a particular incident. The advantage of the distinction between I-positions and we-positions is that there is space for both individual preferences and collective purposes in a group of people who want to work on a problem or task. An individual I-position can be supportive to a we-position but it also can interfere with it when they are conflicting.

Given the complexity of our societal situation, involved as it is in rapid multidirectional changes, the self is 'distributed' in a diversity of actual or possible Iand we-positions. If these positions would go their own way and follow their own behavioral trajectories, the result would be a fragmented and chaotic self. Therefore, the self is in need of some 'higher-order' positions who have the task of creating coherence and organization in the self that prevents it to be entirely determined by the spur of the moment. One of them is a meta-position, comparable with a helicopter-view or bird's eye view, from which a larger variety of specific I-positions can be perceived, compared and evaluated. Such a position enables the person not only to see how one position leads to another one, but also to consider the pattern of positions, that is, the way they are related to each other (e.g., seeing how I-positions together may form a vicious circle). Such a meta-position can be developed in a personal way, for example, via moments of self-reflection, writing a diary, or listening to music, but it can also emerge in a social group involved in a profound conversation. Developing a common meta-position may enrich the contact between teachers and between teachers and students when they want to consider a problem or incident from a long-term perspective.

The meta-position is typically a spatial position allowing an individual, dyad, or group to look at the patterns of positions from a distance perspective. There is 
another position that is particularly valuable from a temporal point of view: the promoter position. This position gives a developmental impetus to a larger group of specific positions. The promoter position has, by its compass function, the power to create orientation and direction in the variety of specific positions and 'move their nose' into the same direction. This special position also has the potential to generate new positions and to create coherence and continuity so that the self is not lost in a multiplicity of possible directions. A promoter position can be located in the internal domain of the self and may be very different for different people. For some it may be 'my mission in life', for others it may be 'I as a spiritual person', or 'I as never giving up', or 'I as overcoming my handicap', or any position that drives the person into a developmental direction that is experienced as meaningful for the self in the long run. A promoter position can also be located in the external domain of the self. It may refer to a political leader, a figure from a book, a hero, a parent, grand-parent, friend or any significant other who is incorporated in the self as a motivating agent for the realization of a personal or social project over a longer time-period. In an educational situation, a most inspiring teacher is the one who is adopted as a promoter position in the external domain of the student's self.

\section{THE IMPORTANCE OF A DIALOGICAL SELF IN OUR CONTEMPORARY WORLD}

For the co-construction of meaning, one of the essences of this special issue, dialogue is quintessential. As a central notion in DST, it is indispensable to understand the relationship between I-positions and their organization and development. Dialogue creates pathways for positions to contact and influence each other. Within-and between dialogues have a significant influence on the relative dominance of $I$ - and we-positions and determine the direction of decision processes.

Dialogues may take place among internal positions in the self (e.g., 'As an answer to the conflict between my position as a teacher and my position as a mother I found a workable solution'), between internal and external positions in the self (e.g., 'As the son of my father I'm used to talking with him about my successes and disappointments and, although he is physically absent, I imagine that he gives me advice') and between external positions of the self (e.g., 'Two colleagues in my school solved their serious conflict and I learned a lot from that'). The dialogical self is not only part of the broader society but functions, moreover, itself as a 'society of mind' with tensions, conflicts, and contradictions as intrinsic features of a healthy functioning self.

However, what do we mean by 'dialogue'? In media exposures it seems to be not more than a buzz word for 'negotiations' and often we notice that non- 
discussible and non-changeable interests are at the background. The problem of this language game is that the most precious potentials of dialogue as a highly fertile and even necessary form of interaction in our boundary-crossing world are covered. Why I' $\mathrm{m}$ I so strongly emphasizing the importance of dialogue in general and for education in particular? The main reason is that in our schools and organizations, and via media communication, we meet people who are very different from us, yet living closely together in a highly compressed world. Living together with people who differ from us qua world view and cultural background challenges our dialogical capacities to the utmost. We need generative forms of dialogue in order to correct or prevent ineffectual and even damaging polarization between cultural and political groups. Another reason for its importance is that there is no infallible individual who can rightly claim the final and exclusive solution to complex problems like climate change, the clash of value systems, robotics and the threat of pandemics. This situation creates an unprecedented challenge for parents and teachers to prepare children for living in a society that is on its way towards a highly discontinuous and only partly predictable future. Faced with such thorny problems, teachers, schools, and institutions can do no better job than bringing different people together who create a common dialogical space for the exploration of possibilities and alternatives which are potentially new to each of the participants and profitable to society as a whole. It is precisely the creation of this dialogical space to which this special issue significantly contributes, not only at the interface between different participants but also within the spaces of the mind of each participant. Therefore, it is so important to create educational situations that have the power to broaden the range of the position repertoire of both teachers and students. Only if this repertoire is broad enough to contain a diversified set of I-positions, can one understand and empathize with people who are different from us, yet connected with us. A heterogeneous society needs a heterogeneous self.

However, the question of 'what is dialogue?' is still insufficiently answered if we do not take into account its innovate potentials and power to create common grounds. An essential feature of a generative dialogue is that one's initial point of view changes by and during the process of interchange. From a dialogical point of view, an opinion is not an end but rather a beginning. As soon as it is formulated, it is subjected to a process in which the initial position is changed and developed during the interchange itself. In dialogue, input and output do not coincide but, instead, the input changes during the process of its formation. Dialogue is not easy and can even be upsetting, because it requires participants to open their initial position to criticism, doubt, and to alternative points of view that may be unfamiliar. It challenges you to change, and sometimes even to give up, your initial position to which you were emotionally attached! Therefore, 
innovation is often associated with pain. However, due to the intense interchange, participants create a common insight, experience, or imagination that deepens and enriches their contact and their perspective on the world. Sharing and innovation facilitate the transition from I-positions to we-positions and back.

Dialogue can only be fully be understood if one realizes that the process is more important than the content of the exchange, as David Bohm has convincingly argued in his influential book On Dialogue (1996). Precisely for that reason, I assume that, for the facilitation of dialogue, one needs to perceive and evaluate communication, both between people and within the self, from the perspective a meta-position. Evaluating the dialogical process from this position, may give us the feeling of moving into the right direction and helps us to find the appropriate 'traveling tools' while moving into uncertain directions. A meta-analysis of what is going on is more decisive for a 'good dialogue' than the content of any preconceived 'right answer'. This does not mean, however, that the content should be isolated from the process, as any good dialogue is driven by empathy with the other and the urge to develop common ground.

The preceding considerations bring me to clearly see what is the highest merit of this special issue. It offers an educational view that understands teacher identity as a dynamic multiplicity of I-positions in the society of mind. It derives its innovative quality from the fact that it heightens and deepens human communication by bringing internal and external dialogues together in a way that is prolific to teachers, students, schools, and society at large.

\section{REFERENCES}

Bohm, David (1996). On Dialogue. New York: Routledge

Hermans, Hubert J. M. (2018). Society in the Self. A theory of identity in democracy. Oxford: Oxford University Press.

Hermans, Hubert J. M., \& Hermans-Konopka, Agnieszka (2010). Dialogical Self Theory: Positioning and counter-positioning in a globalizing society. Cambridge, UK: Cambridge University Press. 


\section{HUBERT HERMANS}

Emeritus professor of psychology at the Radboud University of Nijmegen. Currently he is Honorary President of the International Society for Dialogical Science and President of the International Conferences on the Dialogical Self. He is internationally known as the creator of Dialogical Self Theory.

hhermans@psych.ru.nl

https://orcid.org/0000-0002-8387-0671

\section{FORMATO DE CITACIÓN}

Hermans, Hubert (2020).Foreword by Hubert Hermans. Quaderns de Psicologia, 22(2), e1641. http://dx.doi.org/10.5565/rev/qpsicologia. 1641 